\title{
HYERS-ULAM STABILITY OF THE FIRST ORDER LINEAR DIFFERENTIAL EQUATION FOR BANACH SPACE-VALUED HOLOMORPHIC MAPPINGS
}

\author{
TAKESHi MiURA, HiROKAZU OKA, Sin-EI TAKAHASI \\ AND NORIO NIWA
}

\begin{abstract}
Let $\Omega$ be a convex open set of $\mathbb{C}$, and let $X$ be a complex Banach space. Suppose that $p: \Omega \rightarrow \mathbb{C}$ and $q: \Omega \rightarrow X$ are holomorphic. We give sufficient conditions in order that the first order linear differential equation $f^{\prime}(z)+p(z) f(z)+q(z)=0$ for $X$-valued holomorphic mapping $f: \Omega \rightarrow X$ has the Hyers-Ulam stability.
\end{abstract}

Mathematics subject classification (2000): 34K20, 26D10.

Key words and phrases: Exponential functions, Hyers-Ulam stability.

\section{REFERENCES}

[1] C. AlsinA AND R. GER, On some inequalities and stability results related to the exponential function, J. Inequal. Appl. 2 (1998), 373-380.

[2] T. AOKI, On the stability of the linear transformation in Banach spaces, J. Math. Soc. Japan 2 (1950), 64-66.

[3] Z. GAJDA, On stability of additive mappings, Internat. J. Math. Math. Sci. 14 (1991), 431-434.

[4] R. GER AND P. ŠEMRL, The stability of the exponential equation, Proc. Amer. Math. Soc. 124 (1996), 779-787.

[5] O. Hatori, K. Kobayashi, T. Miura, H. Takagi and S.-E. Takahasi, On the best constant of Hyers-Ulam stability, J. Nonlinear Convex Anal. 5 (2004), 387-393.

[6] D. H. HYERS, On the stability of the linear functional equation, Proc. Nat. Acad. Sci. U.S.A., 27 (1941), 222-224.

[7] D. H. Hyers AND Th. M. Rassias, Approximate homomorphisms, Aequationes Math. 44 (1992), $125-153$.

[8] D. H. Hyers, G. IsAC And Th. M. Rassias, Stability of Functional Equations in Several Variables, Birkhauser, 1998.

[9] T. MiURA, S.-E. TAKAHASI AND S. MiYaJiMa, Hyers-Ulam stability of linear differential operator with constant coefficients, Math. Nachr. 258 (2003), 90-96.

[10] T. MiURA, S.-E. TAKAHASI AND S. MiYAJIMA, A characterization of Hyers-Ulam stability of first order linear differential operators, J. Math. Anal. Appl. 286 (2003), 136-146.

[11] T. Miura, G. HiRASAWA AND S.-E. TAKAHASI, Ger type and Hyers-Ulam stabilities for the first order linear differential operators of entire functions, Int. J. Math. Math. Sci. 22 (2004), 1151-1158.

[12] T. MiURA, S.-M. JUNG AND S.-E. TAKAHASI, Hyers-Ulam-Rassias stability of the Banach space valued linear differential equations $y^{\prime}=\lambda y$, J. Korean Math. Soc. 41 (2004), 995-1005.

[13] T. M. RASSIAS, On the stability of the linear mapping in Banach spaces, Proc. Amer. Math. Soc. 72 (1978), 297-300.

[14] T. M. RASSIAS AND P. ŠEMRL, On the behavior of mappings which do not satisfy Hyers-Ulam stability, Proc. Amer. Math. Soc. 114 (1992), 989-993.

[15] S.-E. TAKahasi, H. TAKagi, T. MiURA AND S. Miyajima, The Hyers-Ulam stability constants of first order linear differential operators, J. Math. Anal. Appl. 296 (2004), 403-409. 
[16] H. TAKAGI, T. MIURA AND S.-E. TAKAHASI, Essential norm and stability constant of weighted composition operators on $C(X)$, Bull. Korean Math. Soc. 40 (2003), 583-591.

[17] S.-E. TAKAHASI, T. MiURA AND S. MiYAJIMA, On the Hyers-Ulam stability of the Banach space-valued differential equation $y^{\prime}=\lambda y$, Bull. Korean Math. Soc. 39 (2002), 309-315.

[18] S. M. UlaM, A collection of mathematical problems, Interscience Tracts in Pure and Applied Mathematics, no. 8, Interscience Publishers, New York-London, 1960. 